\title{
Bezpieczeństwo edukacyjne studentów z obszarów wiejskich
}

\section{Wstęp}

Polska wieś zmienia swoje oblicze, ulegając dynamicznym procesom deruralizacji, dezagraryzacji, restratyfikacji, kształtuje nowy model agrarny, który ją zmienia i różnicuje. Zmiany te wpływają na ludność obszarów wiejskich, która stanowi około $2 / 5$ Polaków, zamieszkujących $93 \%$ powierzchni naszego $\mathrm{kraju}^{1}$. Z badań sondażowych wynika, iż mimo zachodzących przemian gospodarczych, społecznych i kulturowych, polska wieś pozostaje wierna tradycyjnym wartościom, ceniąc sobie częściej niż ludność miast, wiarę religijną i uczciwość, a znacznie rzadziej - towarzystwo, podróże czy dostęp do dóbr kultury². „W opinii większości Polaków typowy mieszkaniec wsi jest religijny (85\%), pracowity (72\%), życzliwy innym (63\%), sprytny i zaradny (55\%), pogodny (53\%), zadbany (52\%), rzadziej - dobrze wykształcony oraz innowacyjny (po 42\%) i oczytany (40\%)" [Nurzyńska i Poczta 2014, s. 169].

To w takiej perspektywie środowiskowej budzą się aspiracje edukacyjne młodzieży, kształtują pragnienia, podejmowane są decyzje dotyczące wyboru dalszej drogi zawodowej i edukacyjnej. Jakimi kryteriami kieruje się młodzież pochodząca ze wsi $\mathrm{w}$ wyborze podjęcia studiów? Na ile powody podjęcia studiów związane są z zaspokojeniem własnych potrzeb edukacyjnych, na ile wiążą się $z$ chęcią zdobycia dobrze płatnego zawodu, a na ile są to pobudki niezwiązane z tymi kryteriami? Jakie są motywy wyboru uczelni i jakie są motywy wyboru kierunku studiów przez młodzież pochodzącą z obszarów wiejskich? Między

\footnotetext{
${ }^{1}$ Centrum Badania Opinii Społecznej, Wieś polska - postawy, styl życia, BS/117/2013, Warszawa 2013, s. 1.

2 Tamże, s. 10.
} 


\section{6}

innymi takie pytania postawili sobie autorzy niniejszego opracowania. Tłem do podjętej problematyki badawczej stał się m.in. raport pt.: „Uwarunkowania decyzji edukacyjnych", w którym określono, że zamieszkiwanie na obszarach wiejskich jest predyspozycją wykluczenia edukacyjnego. Autorzy raportu uznali, iż „wykluczenie edukacyjne znacząco zwiększa prawdopodobieństwo znalezienia się w sferze niedostatku lub nawet skrajnego ubóstwa, ryzyko wykluczenia z rynku pracy, a także wykluczenia w obszarze kompetencji cywilizacyjnych"3.

Uczelnie, pełniąc misję odkrywania i przekazywania wiedzy, kształtowania umiejętności i kompetencji poprzez prowadzenie badań i kształcenie studentów stanowią integralną część narodowego systemu edukacji i nauki ${ }^{4}$. Współpracują z otoczeniem społeczno-gospodarczym, podpisują porozumienia o współpracy, w szczególności w zakresie odbywania praktyk studenckich, prowadzenia badań naukowych i prac rozwojowych oraz określania ich kierunków. Na ile regulacje prawne wyznaczające zakres funkcjonowania szkolnictwa wyższego zostaną wykorzystane przez uczelnie, stwarzając atrakcyjne, pełne nowych możliwości studiowanie i na ile zostanie to dostrzeżone i wykorzystane przez młodzież pochodzącą z obszarów wiejskich.

Analizując dane Narodowego Spisu Powszechnego Ludności i Mieszkań, dotyczące wykształcenia ludności wiejskiej, należy zauważyć, iż w okresie pomiędzy rokiem 2002 a 2011 odsetek osób z obszarów wiejskich mających wykształcenie wyższe i średnie zwiększył się odpowiednio z 4,2 do $9,9 \%$ oraz z 21,5 do $25,5 \%$ (w miastach odpowiednio z 13,2 do 21,4 oraz z 37,3 do 35,3 ) 5 . Na taki stan mógł mieć niewątpliwie wpływ wzrost możliwości kontynuacji edukacji oraz wzrost migracji na obszary wiejskie osób z wykształceniem średnim i wyższym.

Analiza kapitału ludzkiego obszarów wiejskich wśród jego mocnych stron wyróżnia m.in.: dodatni bilans migracji miasto-wieś, trend wzrostu wykształcenia ludności wiejskiej ogółem, poprawę dostępności kształcenia na poziomie przedszkolnym, poprawę jakości kształcenia na poziomie podstawowym i średnim, wzrost liczby i poprawę dostępności przestrzennej uczelni wyższych, podniesienie kwalifikacji zawodowych i dostosowanie ich do potrzeb rynku pracy. Tym samym wskazuje się również na słabe strony wyszczególnione $\mathrm{w}$ analizie SWOT kapitału ludzkiego obszarów wiejskich, do których należą m.in.: niska

\footnotetext{
${ }^{3}$ Instytut Badań Edukacyjnych, Raport tematyczny z badania: Uwarunkowania decyzji edukacyjnych, Warszawa 2014, s. 18.

${ }^{4}$ Ustawa z dnia 27 lipca 2005 r. Prawo o szkolnictwie wyższym (Dz.U. 2005 Nr 164, poz. 1365 z późn. zm.), art. 4 ust. 3.

${ }^{5}$ Narodowy Spis Powszechny Ludności i Mieszkań 2011, Ludność. Stan i struktura demograficzno-społeczna, GUS, Warszawa 2013, za: I. Nurzyńska, W. Poczta (red.), Polska wieś 2014. Raport o stanie wsi, FDPA, Wydawnictwo Naukowe Scholar, Warszawa 2014, s. 50.
} 
mobilność zawodowa, bezrobocie, w tym osób młodych, poniżej 24. roku życia, powodujące m.in. brak możliwości zdobycia doświadczenia zawodowego, wzrost współczynników obciążenia demograficznego grupą wieku poprodukcyjnego, zmniejszanie się liczby osób w wieku prokreacyjnym, wysoką „,wrażliwość" kapitału ludzkiego na niekorzystne uwarunkowania społeczno-ekonomiczne i jego podatność na polaryzację [Rakowska i Wojewódzka-Wiewiórska 2010, s. 9-11].

Dużym wsparciem dla obszarów wiejskich są programy rządowe oraz możliwość pozyskania środków na realizację projektów z funduszy strukturalnych, również na płaszczyźnie edukacji. Jednym z takich projektów, w kontekście eliminowania barier w dostępie ludności wiejskiej do pełnej oferty edukacyjnej, kulturalnej, informacyjnej i sportowej w celu zmniejszenia różnic między miastem a wsią, był Rządowy Program Rozwoju Edukacji na Obszarach Wiejskich na lata 2008-2013. Celem strategicznym projektu był rozwój edukacji oraz podniesienie jakości i poziomu wykształcenia mieszkańców wsi z obszarów wiejskich ${ }^{6}$. Analizując realizację działań podjętych $\mathrm{w}$ ramach realizowanych priorytetów oraz osiagniętych $\mathrm{w}$ ramach ich realizacji wskaźników, można wysnuć wnioski, iż działania te były nastawione na zdiagnozowane potrzeby mieszkańców obszarów wiejskich. Można zatem zauważyć, iż dobra analiza potrzeb, słabych i mocnych stron obszarów wiejskich, daje możliwość reagowania i niwelowania różnic w konfrontacji z obszarami miejskimi.

Egzemplifikacji tego typu badań można doszukać się również w podjętej analizie potrzeb edukacyjnych studentów z obszarów wiejskich w zakresie poznania powodów podjęcia studiów, motywów wyboru kierunku studiów i uczelni, a także oczekiwań co do oferty edukacyjnej, społecznej i kulturalnej oraz zapotrzebowania na kompetencje w trakcie studiów. Celem artykułu jest budowa profilu studenta $\mathrm{z}$ obszaru wiejskiego $\mathrm{z}$ uwzględnieniem płci w kontekście zaspokajania potrzeb i aspiracji edukacyjnych, służących zapewnieniu bezpieczeństwa edukacyjnego studentom oraz podnoszeniu jakości kształcenia na uczelni.

\section{Organizacja badań}

Badaniami objęto 710 studentów pierwszego roku Państwowej Szkoły Wyższej im. Papieża Jana Pawła II w Białej Podlaskiej, z czego 331 osób (46,6\%) zamieszkuje obszary wiejskie - głównie w powiatach: bialskim, siedleckim,

\footnotetext{
${ }^{6}$ Ministerstwo Edukacji Narodowej, Sprawozdanie z realizacji w 2013 r. Programu Rozwoju na Obszarach Wiejskich na lata 2008-2013 oraz podsumowanie działań z całego okresu trwania programu, projekt z 17.10.2014 r., Warszawa 2014, s. 96.
} 


\section{8}

łukowskim, parczewskim oraz włodawskim ${ }^{7}$. W grupie studentów z obszarów wiejskich $63 \%$ stanowiły kobiety i $37 \%$ mężczyźni. Badanie przeprowadzono metodą sondażu diagnostycznego 1 października 2014 roku, a podstawowym narzędziem badawczym był autorski kwestionariusz ankiety, stanowiący narzędzie badawcze Wewnętrznego Systemu Zapewnienia Jakości Kształcenia na Uczelni (Załącznik 4 do WSZJK) ${ }^{8}$. Wyniki badań poddano analizie statystycznej przy użyciu programu STATISTICA 10. Ze względu na charakter zadawanych pytań (pytania wielokrotnego wyboru) obliczono procent wskazań każdej odpowiedzi na poszczególne pytanie oraz zbadano istnienie zależności istotnych statystycznie w odniesieniu do płci badanych. Przyjęto poziom istotności $p=0,05$. Odpowiedzi studentów wykazujące zależność istotną statystycznie oznaczono gwiazdką (*).

Młodzi ludzie, po zdaniu egzaminu maturalnego, najczęściej rozpatrują dwie alternatywy: pójście na studia wyższe lub podjęcie pracy zawodowej. Dochodzi do tego wiele czynników wpływających na podjęcie decyzji o dalszej drodze życiowej [Jarecki 2008]. Badania motywów wyboru studiów wyższych były prowadzone w Polsce od lat 70. ubiegłego wieku, m.in. przez Liberską [1974], czy Sikorską i Białeckiego [1997]. Również Główny Urząd Statystyczny partycypował w badaniach $\mathrm{z}$ tego zakresu? .

Mając powyższe na uwadze, w przeprowadzonych analizach można zauważyć odzwierciedlenie wyników badań w zakresie motywów wyboru zarówno uczelni, jak i kierunków studiów.

Uwzględniając cel artykułu oraz odnosząc się do próby badawczej, stwierdza się, iż występują różnice w wyborze kierunków studiów w zależności od miejsca zamieszkania. Studenci z obszarów wiejskich dominują na kierunkach takich jak zarządzanie, finanse i rachunkowość, informatyka, ekonomia oraz gospodarka przestrzenna. Najmniej liczną reprezentację stanowią badani na turystyce i rekreacji, zdrowiu publicznym, socjologii oraz filologii rosyjskiej.

Biorąc pod uwagę studentów z obszarów wiejskich z uwzględnieniem płci, najczęściej wybieranymi kierunkami studiów przez kobiety były: ekonomia (93,33\% studentów na kierunku stanowią kobiety), fizjoterapia, pedagogika oraz pielegniarstwo (po blisko 90\% wyborów). Najwięcej zaś mężczyzn wybrało kierunek ratownictwo medyczne (blisko 91\%), informatykę (ponad 86\%) oraz rolnictwo (blisko 78\%).

\footnotetext{
${ }^{7}$ Dane pochodzą z Systemu Obsługi Szkół Wyższych BAZUS PSW im. Papieża Jana Pawła II w Białej Podlaskiej.

${ }^{8}$ Załącznik 4 do Wewnętrznego Systemu Zapewnienia Jakości Kształcenia w Państwowej Szkole Wyższej im. Papieża Jana Pawła II w Białej Podlaskiej zatwierdzonego Uchwałą nr 14/2012 Senatu Państwowej Szkoły Wyższej im. Papieża Jana Pawła II w Białej Podlaskiej z dnia 02.03.2012 r. (z późn. zm.).

${ }^{9}$ Główny Urząd Statystyczny, Ścieżki edukacyjne Polaków, Warszawa 2005.
} 


\section{Analiza wyborów edukacyjnych mieszkańców wsi}

W badaniach Głównego Urzędu Statystycznego w grupie motywów wyboru nauki w szkole wyższej dominują: możliwość znalezienia dobrej pracy oraz rozwój zainteresowań (odpowiednio $68,8 \%$ oraz $61,3 \%$ wskazań badanych w grupie osób studiujących lub po studiach, ale mających do 30 lat $)^{10}$.

Odnosząc efekty badań GUS do badań będących przedmiotem artykułu, można stwierdzić zbieżność tych efektów. Przyjmując zdobycie dobrze płatnego zawodu jako odpowiedź zbliżoną do możliwości znalezienia dobrej pracy oraz zaspokojenie własnych potrzeb intelektualnych zbliżone do rozwoju zainteresowań należy zauważyć, iż wskazane motywy podjęcia studiów przez grupę badanych w PSW w Białej Podlaskiej są podobne. Różnica dotyczy tylko wartości procentowej. W związku z czym w prowadzonych badaniach $\mathrm{w}$ grupie powodów podjęcia studiów pojawiły się zdecydowanie sprecyzowane motywy: zdobycie dobrze płatnego zawodu (średnio 46,4\% wskazań badanych), zaspokojenie własnych potrzeb intelektualnych (średnio 32,9\%) oraz uzyskanie dyplomu uczelni wyższej (średnio 24,6\%). Zależność istotna statystycznie wystąpiła w przypadku zaspokojenia własnych potrzeb intelektualnych. Oznacza to, iż grupa kobiet w większym stopniu niż grupa mężczyzn jako powód wskazuje zaspokojenie własnych potrzeb intelektualnych. Warto zauważyć, iż badani w minimalnym stopniu wskazywali na inne odpowiedzi. Opinia rodziny, opinia znajomych oraz studia jako sposób spędzenia czasu zostały wybrane tylko przez nielicznych badanych.

Głównymi motywami wyboru uczelni w grupie kobiet zamieszkujących obszary wiejskie były: bliskość uczelni od miejsca zamieszkania, prestiż uczelni oraz niższe niż w innych miastach koszty utrzymania. Mężczyźni natomiast przy wyborze uczelni pod uwagę wzięli jej bliskość od miejsca zamieszkania, informację, że znajomi tutaj studiują oraz prestiż. W analizowanych motywach wyboru uczelni wystąpiła zależność istotna statystycznie z uwzględnieniem płci. W przypadku uczelnianej infrastruktury, kobiety dwukrotnie bardziej niż ich koledzy doceniły nowoczesne budynki oraz akademik.

Największy wpływ na wybór kierunku studiów zarówno u kobiet, jak i u mężczyzn miały: zbieżność z zainteresowaniami (średnio 59,5\% wskazań badanych), perspektywa znalezienia pracy (średnio 51,4\%) oraz perspektywa wysokich zarobków (średnio 22,4\%). Zależność istotna statystycznie wystapiła przy perspektywie znalezienia pracy na korzyść kobiet, co oznacza, iż motyw ten jest bardziej istotny dla kobiet niż mężczyzn. Wyniki badań są zbieżne z motywami wyboru kierunku studiów dla ogółu osób studiujących lub mających do 30 lat w badaniach prowadzonych przez GUS, z których wynika, że najważniejszymi

${ }^{10}$ Tamże, s. 124. 
motywami są: zgodność kierunku z zainteresowaniami (69,5\%) oraz możliwość znalezienia dobrej pracy $(60,0 \%)^{11}$. Podobnie w badaniach przeprowadzonych przez Sekułę-Kwaśniewicz [2003] na grupie młodzieży z małych miast, głównymi motywatorami wyboru kierunku studiów były: zgodność z zainteresowaniami, powiązanie ze zdolnościami, gwarancja dobrze płatnej pracy oraz przygotowanie do dobrego zawodu.

Można zatem dostrzec podobieństwa w preferencjach wyboru kierunku studiów przez maturzystów oraz ich aktualność. Co istotne, wybór ten wykazuje synergię opartą na samorealizacji, a także silne zakorzenienie przekonania o konieczności podejmowania takich decyzji w kontekście szans na rynku pracy [Kucharski i Ligocka 2012, s. 55 ].

Głównym źródłem informacji na temat wybranego kierunku studiów i uczelni okazał się Internet (ponad 90\% wskazań), opinia rodziny lub znajomych (ponad $25 \%$ ), polecenie uczelni przez studiujących kolegów oraz broszury, ulotki i billboardy (po ok. 17\% odpowiedzi). Minimalne znaczenie (mniej niż 6\% wskazań) jako źródło informacji o uczelni ma prasa, radio, telewizja, spoty reklamowe, spotkania w szkołach czy portale edukacyjne.

Efektem wielu badań jest stwierdzenie, że Internet to dominujące źródło w kształtowaniu możliwości edukacyjnych oraz w budowaniu procesu kształcenia. Zdaniem m.in. Błaszczykiewicza czy Szpunar [2006] oraz autorów niniejszego opracowania, Internet jest ważnym narzędziem w pozyskiwaniu informacji, które są potrzebne do podjęcia działań związanych z edukacją oraz zdobywania informacji o otaczającym świecie (w badaniach Błaszczykiewicza 89\% młodzieży wskazuje na to źródło). Co więcej, zauważono również dużo mniejszy udział w wyborze drogi życiowej oraz ścieżki edukacyjnej roli mass mediów (prasa, radio, telewizja) oraz specjalistów (np. doradców zawodowych) ${ }^{12}$.

Oczekiwania badanych studentów z obszarów wiejskich dotyczące oferty edukacyjnej, społecznej i kulturalnej okazały się być bardzo zróżnicowane. Kobiety najbardziej liczą na spotkania z ciekawymi ludźmi, wyjazdy studyjne, wycieczki naukowe, kursy językowe oraz możliwości odbycia praktyk/staży zagranicznych w trakcie studiów. Mężczyźni natomiast chcieliby spotykać się z ciekawymi ludźmi, realizować zajęcia sportowe, kursy komputerowe oraz kursy językowe. Zależność istotna statystycznie wystapiła w przypadku kursów językowych, wolontariatu, spotkań z ciekawymi ludźmi, wyjazdów studyjnych, wycieczek naukowych, obozów integracyjnych oraz możliwości odbycia praktyk/staży zagranicznych w trakcie nauki na korzyść kobiet oraz w odniesieniu do kursów komputerowych i zajęć sportowych na korzyść mężczyzn.

\footnotetext{
${ }^{11}$ Tamże, s. 131.

${ }^{12}$ www.błaszczykiewicz.pl//kategoria/badania-naukowe (data dostępu: 21.11.2014).
} 
W trakcie studiów kobiety, podobnie jak i mężczyźni chcieliby opanować głównie umiejętność współpracy. Na dalszym miejscu kobiety doceniły umiejętności wykorzystania zdobytej wiedzy w praktyce, kreatywność oraz jasne i przekonywujące komunikowanie się. Mężczyźni natomiast pragną opanować kreatywność, realizację celów, umiejętności wykorzystania zdobytej wiedzy w praktyce oraz podejmowania decyzji. Istotne statystycznie różnice zaznaczyły się w jasnym i przekonywującym komunikowaniu się, rozwiązywaniu problemów, asertywności, poczuciu własnej wartości oraz umiejętności wykorzystania zdobytej wiedzy w praktyce na korzyść kobiet oraz w przywództwie na korzyść mężczyzn.

Niezależnie od płci, większość badanych po ukończeniu studiów zamierza szukać pracy (ponad 70\% wskazań) lub kontynuować naukę (średnio 35\% odpowiedzi). Zależność istotna statystycznie w odniesieniu do płci wystąpiła w przypadku planowania wyjazdu za granicę. Dwukrotnie więcej kobiet (blisko 20\%) niż mężczyzn uwzględniło taką możliwość. Tylko nieliczni chcą kontynuować aktualną pracę lub nie mają jeszcze żadnych planów.

\section{Profil studenta i studentki z obszarów wiejskich}

Przeprowadzone analizy i wnioskowanie pozwalają na budowę profilu studenta i studentki zamieszkujących obszary wiejskie. Wybór cechy determinowała wartość zmiennej w odniesieniu do płci. W tabeli 1 zestawiono wartości jakościowe wyszczególnionych cech składających się na profil studenta: powód podjęcia studiów, motyw wyboru uczelni, źródła poszukiwania informacji na temat wybranego kierunku studiów i uczelni, oczekiwania w zakresie oferty edukacyjnej, społecznej i kulturalnej, kompetencje do opanowania w trakcie studiów oraz plany na przyszłość.

Przy tworzeniu profilu studenta wzięto pod uwagę tylko te cechy, w których wystąiła zależność istotna statystycznie w odniesieniu do płci, co pozwoliło wykazać różnice wynikające z płci, a nie obszaru pochodzenia. W związku z czym kobieta studiująca w PSW w Białej Podlaskiej pochodząca $\mathrm{z}$ obszaru wiejskiego kieruje się innym powodem podjęcia studiów, motywem wyboru uczelni i kierunku studiów niż mężczyzna. Kobieta ma inne oczekiwania w zakresie oferty edukacyjnej, społecznej i kulturalnej niż student płci męskiej z obszarów wiejskich, co skutkuje także odmiennymi oczekiwaniami w obszarze zapotrzebowania na kompetencje oraz planami na przyszłość. Można zatem stwierdzić, iż studentka PSW podejmuje studia, by zaspokoić własne potrzeby intelektualne w celu znalezienia pracy, kierując się nowoczesną infrastrukturą uczelni. Uważa, iż w trakcie kształcenia należałoby organizować spotkania z ciekawymi ludźmi, 
Tabela 1

Szczegółowy profil studenta z obszarów wiejskich z uwzględnieniem płci

\begin{tabular}{|c|c|c|}
\hline Wyszczególnienie cech & Kobiety & Mężczyźni \\
\hline Powody podjęcia studiów & $\begin{array}{l}\text { zaspokojenie własnych potrzeb intelektual- } \\
\text { nych }\end{array}$ & - \\
\hline Motywy wyboru uczelni & infrastruktura uczelni & - \\
\hline motywy wyboru kierunku & perspektywa znalezienia pracy & - \\
\hline $\begin{array}{l}\text { Oczekiwania w zakresie } \\
\text { oferty edukacyjnej, } \\
\text { społecznej i kulturalnej }\end{array}$ & $\begin{array}{l}\text { spotkania z ciekawymi ludźmi, wyjazdy stu- } \\
\text { dyjne/wycieczki naukowe, kursy językowe }\end{array}$ & $\begin{array}{l}\text { zajęcia } \\
\text { sportowe, kursy } \\
\text { komputerowe }\end{array}$ \\
\hline $\begin{array}{l}\text { Zapotrzebowanie } \\
\text { na kompetencje }\end{array}$ & $\begin{array}{l}\text { umiejętności wykorzystania zdobytej wiedzy } \\
\text { w praktyce, jasne i przekonujące komuniko- } \\
\text { wanie się, rozwiązywanie problemów }\end{array}$ & przywództwo \\
\hline Plany na przyszłość & wyjazd za granicę & brak planów \\
\hline
\end{tabular}

Źródło: Opracowanie własne.

wyjazdy naukowe, kursy językowe oraz zgłasza zapotrzebowanie na takie umiejętności, jak wykorzystanie zdobytej wiedzy w praktyce, jasne i przekonujące komunikowanie się, rozwiązywanie problemów. Po ukończeniu nauki, dwukrotnie częściej niż mężczyzna, planuje wyjazd za granicę.

Uwzględnione kryterium zależności istotnej statystycznie w przypadku studentów mężczyzn z obszarów wiejskich skutkuje brakami wskazań w odniesieniu do powodów podjęcia studiów, motywów wyboru uczelni oraz kierunku studiów. W związku z powyższym możliwe jest stwierdzenie, iż oczekiwania badanych płci męskiej w zakresie oferty edukacyjnej, społecznej i kulturalnej odnoszą się do organizacji zajęć sportowych i kursów komputerowych. Zgłaszane zapotrzebowanie na rozwój kompetencji dotyczy głównie przywództwa. Co istotne, grupę badanych mężczyzn, sześciokrotnie częściej niż u kobiet, cechuje brak planów na przyszłość po ukończeniu kształcenia.

\section{Podsumowanie i wnioski}

Podjęcie decyzji o studiach wyższych w grupie osób z obszarów wiejskich ma na celu eliminację predyspozycji wykluczenia edukacyjnego, gdyż zgodnie z opinią ekspertów „osoby wykluczone z edukacji na poziomie szkoły wyższej są to jednocześnie osoby, których najwyższy ukończony poziom nauki to szkoła średnia z maturą lub szkoła pomaturalna/policealna"13. Co ważne, zasięg wyklu-

\footnotetext{
${ }^{13}$ Instytut Badań Edukacyjnych, Raport tematyczny z badania: Uwarunkowania decyzji edukacyjnych, Warszawa 2014, s. 153.
} 
czenia edukacyjnego maleje w większych miastach, w związku z tym naturalne wydaje się zaspokajanie potrzeb edukacyjnych na poziomie studiów wyższych.

Wyniki prowadzonych badań wpisują się w badania prowadzone od lat 70 . XX wieku w Polsce. Zgodność wyników badań dotyczy powodów podjęcia studiów, motywów wyboru kierunków studiów oraz źródeł informacji. Dodatkowo analiza badań prowadzonych na grupie 331 studentów z obszarów wiejskich umożliwiła postawienie następujących wniosków:

1. W ofercie edukacyjnej uczelni jest grupa kierunków studiów zdominowanych przez osoby z obszarów wiejskich.

2. Już na poziomie wyboru kierunku studiów występuje zróżnicowanie w odniesieniu do płci. Kobiety wybierają inne kierunki studiów niż mężczyźni.

3. Podjęcie próby zbadania zależności istotnych statystycznie między badanymi zmiennymi a płcią umożliwiła konstrukcję profili studentki oraz studenta pochodzących z obszarów wiejskich, które pozwalają dostrzec dywersyfikację we wskazaniach badanych.

4. Można stwierdzić, iż kobiety $\mathrm{z}$ obszarów wiejskich w większym stopniu zgłaszają zapotrzebowanie na naukę oraz rozwój kompetencji niż mężczyźni. Precyzyjniej też wskazują powody podjęcia studiów oraz wyboru uczelni i kierunku studiów.

5. Wiodącym źródłem informacji $\mathrm{w}$ grupie studentów $\mathrm{z}$ obszarów wiejskich jest Internet. Znikome znaczenie ma prasa, radio oraz telewizja.

Mając powyższe na uwadze oraz odnosząc się do bezpieczeństwa edukacyjnego należy stwierdzić, iż miejsce zamieszkanie oraz płeć wpływają na wiele cech kształtujących to bezpieczeństwo, poprzez budowę adekwatnej oferty edukacyjnej, włączanie kompetencji w efekty kształcenia modułów/przedmiotów, a także właściwą politykę komunikacyjną. Pozyskiwanie informacji w tym zakresie, poprzez badanie interesariuszy, pozwala kierować działaniami mającymi na celu zapewnienie bezpieczeństwa edukacyjnego.

Efektem prowadzonych badań jest rekomendacja wdrożenia wniosków pochodzących z badań w politykę uczelni, tym samym przyczyniając się do stałej poprawy jakości kształcenia.

\section{Literatura}

Centrum Badania Opinii Społecznej, Wieś polska - postawy, styl życia, BS/117/2013, Warszawa 2013.

Główny Urząd Statystyczny, Ścieżki edukacyjne Polaków, Warszawa 2005.

Instytut Badań Edukacyjnych, Raport tematyczny z badania: Uwarunkowania decyzji edukacyjnych, Warszawa 2014.

JARECKI W., 2008: Motywy wyboru studiów i kierunku studiów wyższych, Prace i Studia Wydziału Nauk Ekonomicznych i Zarządzania 3, 143-154. 
KUCHARSKI A., LIGOCKA M., 2012: Maturzyści o motywach i źródtach poszukiwania informacji dotyczqcych studiów, Opuscula Sociologica 1, 45-57.

LIBERSKA B., 1974: Problemy efektywności kształcenia wyższego, PWN, Warszawa.

Ministerstwo Edukacji Narodowej, Sprawozdanie z realizacji w 2013 r. Programu Rozwoju na Obszarach Wiejskich na lata 2008-2013 oraz podsumowanie działań z całego okresu trwania programu, Projekt z 17.10.2014 r., Warszawa 2014.

NURZYŃSKA I., POCZTA W. (red.), 2014: Polska wieś 2014. Raport o stanie wsi, FDPA, Wydawnictwo Naukowe Scholar, Warszawa.

RAKOWSKA J., WOJEWÓDZKA-WIEWIÓRSKA A., 2010: Zróżnicowanie przestrzenne obszarów wiejskich $w$ Polsce - stan i perspektywy rozwoju w kontekście powiqzań funkcjonalnych, Ekspertyza wykonana na zamówienie Ministerstwa Rozwoju Regionalnego, Warszawa.

SEKUŁA-KWAŚNIEWICZ H., 2003: Dominujace wartości $w$ dą̇eniach maturzystów z matych ośrodków miejskich, [w:] B. Idzikowski, E. Narkiewicz-Niedbalec, M. Zielińska, E. Papiór (red.), Młodzież polska w nowym ładzie społecznym, Uniwersytet Zielonogórski, Zielona Góra.

SIKORSKA J., BIAŁECKI I., 1997: Wyksztatcenie i rynek, Wydawnictwo Tepis, Warszawa.

SZPUNAR M., 2006: Internet a nowoczesna eduk@cja - czy istnieje jakaś alternatywa?, SCENO Zeszyty Naukowe 2.

Ustawa z dnia 27 lipca 2005 r. Prawo o szkolnictwie wyższym (Dz.U. 2005 Nr 164, poz. 1365 z późn. zm.).

www.błaszczykiewicz.pl//kategoria/badania-naukowe (data dostępu: 21.11.2014).

Załącznik 4 do Wewnętrznego Systemu Zapewnienia Jakości Kształcenia w Państwowej Szkole Wyższej im. Papieża Jana Pawła II w Białej Podlaskiej zatwierdzonego Uchwałą nr 14/2012 Senatu Państwowej Szkoły Wyższej im. Papieża Jana Pawła II w Białej Podlaskiej z dnia 02.03.2012 r. (z późn. zm.).

\section{Abstrakt}

Uczelnie pełnią misję odkrywania i przekazywania wiedzy, rozwoju kompetencji poprzez prowadzenie badań i kształcenie studentów. Podjęcie decyzji o studiach wyższych w grupie osób z obszarów wiejskich ma na celu eliminację predyspozycji wykluczenia edukacyjnego. Celem artykułu jest budowa profilu studenta z obszaru wiejskiego z uwzględnieniem płci w kontekście zaspokajania potrzeb i aspiracji edukacyjnych, służących zapewnieniu bezpieczeństwa edukacyjnego. Przy tworzeniu profilu studenta wzięto pod uwagę tylko te cechy, w których wystąpiła zależność istotna statystycznie w odniesieniu do płci. Wyniki analiz wpisują się w badania prowadzone od lat 70. XX wieku w Polsce. Zgodność wyników badań dotyczy powodów podjęcia studiów, motywów wyboru kierunków studiów oraz źródeł informacji.

Słowa kluczowe: obszary wiejskie, bezpieczeństwo edukacyjne, szkoła wyższa 


\title{
Educational safety of students from rural areas
}

\begin{abstract}
It is the universities' duty to discover and transmit knowledge and competences through scientific research and educating students. Decision to undertake university studies, among people from rural areas, is aimed at eliminating the possibility of educational exclusion. The aim of the article is to build a profile of a student from rural areas, divided by gender, in the context of meeting the needs and aspirations connected with education. When creating the student profile, only those characteristics that occurred statistically significant relationship with respect to gender, were taken into account. The results correspond with research conducted since the seventies of the twentieth century in Poland. There are similar results concerning the reasons to undertake tertiary education, choice of the faculties, and sources of information concerning studies.
\end{abstract}

Key words: rural areas, safety education, university 
